\title{
Immunomodulatory Effects of Palladium(II) Complexes of 1,2,4-Triazole on Murine Peritoneal Macrophages
}

\author{
Amadeu M. Bego, ${ }^{a}$ Regina C. G. Frem, ${ }^{*, a}$ Adelino V. G. Netto, ${ }^{a}$ Antonio E. Mauro, ${ }^{a}$ \\ Sandra R. Ananias, ${ }^{b}$ Iracilda Z. Carlos ${ }^{b}$ and Michelle C. da Rocha ${ }^{b}$ \\ ${ }^{a}$ Departamento de Química Geral e Inorgânica, Instituto de Química de Araraquara, \\ Universidade Estadual Paulista, PO Box 355, 14801-970 Araraquara-SP, Brazil \\ ${ }^{b}$ Departamento de Análises Clínicas, Faculdade de Ciências Farmacêuticas de Araraquara, \\ Universidade Estadual Paulista, PO Box 502, 14801-902 Araraquara-SP, Brazil
}

\begin{abstract}
Os complexos polinucleares $\left[\left\{\mathrm{PdCl}_{2}(\mu-\mathrm{Htrz})\right\}_{n}\right](\mathbf{1})$ e $\left[\left\{\mathrm{PdBr}_{2}(\mu-\mathrm{Htrz})\right\}_{n}\right](\mathbf{2})(\mathrm{Htrz}=1,2,4$-triazol $)$ foram sintetizados neste trabalho. $\mathrm{O}$ composto 1 foi preparado a partir da substituição da acetonitrila do precursor $\left[\mathrm{PdCl}_{2}(\mathrm{MeCN})_{2}\right]$ pelo 1,2,4-triazol. A adição posterior de brometo de potássio ao meio reacional resultou na formação do complexo 2 . Os complexos inéditos foram isolados, purificados e caracterizados por análise elementar, espectroscopias vibracional no infravermelho e eletrônica no UV-visível e curvas de análise termogravimétrica (TG). Os resultados experimentais sugerem que, em ambos os casos, a coordenação do 1,2,4-Htrz ocorra via átomos $\mathrm{N}(2)$ e $\mathrm{N}(4)$, atuando como pontes entre centros de paládio. O poliedro de coordenação quadrado-planar ao redor do paládio(II) é determinado pelos dois átomos de $\mathrm{N}$ do heterociclo e por dois ligantes cloro (1) ou bromo (2), em uma provável configuração trans. As curvas TG indicaram que a natureza do ligante aniônico não afeta significativamente a estabilidade térmica de $\mathbf{1}$ e $\mathbf{2}$. Os produtos finais de decomposição térmica foram identificados como paládio metálico pela técnica de difratometria de raios $\mathrm{X}$ de pó. Testes preliminares envolvendo a avaliação dos efeitos dos compostos $\mathbf{1}, \mathbf{2}$ e Htrz na produção de $\mathrm{H}_{2} \mathrm{O}_{2}$ e $\mathrm{NO}$ em culturas de macrófagos peritoneais de camundongos $\mathrm{BALB} / \mathrm{c}$ foram realizados in vitro.
\end{abstract}

The 1,2,4-triazolyl-bridged polynuclear complexes $\left[\left\{\mathrm{PdCl}_{2}(\mu \text {-Htrz })\right\}_{n}\right](\mathbf{1})$ and $\left[\left\{\mathrm{PdBr}_{2}(\mu \text {-Htrz })\right\}_{n}\right](\mathbf{2})$ have been obtained in this work. Compound $\mathbf{1}$ is prepared by the displacement of acetonitrile from $\left[\mathrm{PdCl}_{2}(\mathrm{MeCN})_{2}\right]$ by 1,2,4-triazole (Htrz). Further addition of potassium bromide to the reaction medium afforded complex $\mathbf{2}$. The new complexes have been isolated, purified and characterized by means of elemental analysis, IR and UV-visible electronic spectroscopies and thermogravimetric (TG) curves. The experimental data suggested that, in both cases, the coordination of 1,2,4-Htrz takes place through the $\mathrm{N}(2)$ and $\mathrm{N}(4)$ atoms, bridging the palladium centers. The square-planar coordination polyhedron of palladium(II) is determined by two nitrogen atoms from the triazole ligands, while the other two coordination positions are occupied by the chloro (1) or bromo (2) ligands. TG curves indicated that the nature of the anionic ligand does not affect significantly the thermal stability of $\mathbf{1}$ and $\mathbf{2}$. The final products of the thermal decompositions were identified as metallic palladium by X-ray powder diffractometry. Preliminary tests involving the evaluation of the effects of compounds $\mathbf{1}, 2$ and $\mathrm{Htrz}$ on $\mathrm{H}_{2} \mathrm{O}_{2}$ and $\mathrm{NO}$ production in cultures of peritoneal macrophages from $\mathrm{BALB} / \mathrm{c}$ mice were carried out in vitro.

Keywords: palladium(II) complexes, 1,2,4-triazole, macrophages, nitric oxide, hydrogen peroxide

\section{Introduction}

One of the first cells to respond to invasion by pathogens and tumor cells are macrophages, which play a pivotal role

\footnotetext{
*e-mail: rcgfrem@iq.unesp.br
}

in the development of specific and non specific immune response. When appropriately activated, macrophages are capable of killing pathogens and tumor cells by a number of processes that can involve the phagocytosis of foreign particles and the production and release of numerous soluble cytotoxic molecules such as cytokines (e.g. tumor 
necrosis factor, TNF- $\alpha$ ), reactive oxygen intermediates (ROI) and reactive nitrogen intermediates (RNI). ${ }^{1-3}$ Hydrogen peroxide $\left(\mathrm{H}_{2} \mathrm{O}_{2}\right)$ and nitric oxide $(\mathrm{NO})$ are reactive oxygen and nitrogen intermediates essential in cell signaling and are effector molecules for the microbicidal and cytotoxic response of macrophages after stimulation., Nitric oxide and reactive oxygen species affect virtually every step of the development of inflammation. Large amounts of NO, generated primarily by inducible nitric oxide synthase (iNOS) can be toxic and pro-inflammatory. Similarly, $\mathrm{O}_{2}^{-}$produced by NADPH oxidases may lead to toxic effects, when produced at high levels during oxidative burst. ${ }^{6}$ Despite the fact that nitric oxide is not a strong oxidant, $\mathrm{NO}$ reacts at a nearly diffusion limited rate with superoxide to yield peroxynitrite (-OONO), a strong oxidant. Activated inflammatory cells and agoniststimulated endothelial cells generate peroxynitrite which is able to oxidize several biological molecules to nitrate or protein tyrosine residues and other phenolics. ${ }^{7,8}$ When iNOS is synthesized, it releases higher NO quantities than constitutive nitric oxide synthase (cNOS) and the production of NO continues until $L$-arginine or the cofactors are depleted or when cellular death occurs. ${ }^{9}$ Prolonged exposure to a large amount of NO, as in activation of iNOS, inhibits the activity of several enzymes, such as aconitase, cytochrome $c$ oxidase and ribonucleotide reductase. Thus, NO may become cytotoxic or cytostatic. ${ }^{10}$ Of considerable therapeutic value are the agents that modulate the activity of NO. In particular, those that reduce the formation of NO may be beneficial in pathophysiological conditions where excessive production of NO is a contributory factor. These include diseases such as septic shock, neurodegenerative disorders, and inflammation. ${ }^{11}$ It is worth to point out that agents with strong anti-inflammatory and anti-oxidative activities may display anti-tumor properties since tumor promotion is closely linked to inflammation and oxidative stress. $^{12}$

Some authors have shown that murine macrophages treated with cisplatin become activated and acquire enhanced capacity to lyse tumor cells in vitro, produce increased amount of interleukin-1 (IL-1) and TNF, reactive oxygen metabolites (ROI), reactive nitrogen intermediates (RNI), lysozyme and arginase. ${ }^{13}$ The fact that cisplatin can be used not only as an antitumor drug but also as a potent non-specific immunopotentiating agent has prompted us to initiate a research program in order to synthesize new metal-based compounds with the ability to enhance the host defense responses. Our previous results have indicated that the release of $\mathrm{H}_{2} \mathrm{O}_{2}$ levels in cultures of activated mice peritoneal macrophages was increased in the presence of compounds of the type $[\mathrm{PdX}(\mathrm{dmba})(\mathrm{dppp})](\mathrm{X}=\mathrm{Cl}$,
$\mathrm{N}_{3}, \mathrm{NCO}, \mathrm{NCS} ; \mathrm{dmba}=N, N$-dimethylbenzylamine; dppp $=1,3$-bis (diphenylphosphine)propane). ${ }^{14}$

Metal-based compounds of 1,2,4-triazole have received attention due to their potential uses as antimicrobial and antitumoral drugs. ${ }^{15,16} 1,2,4$-Triazoles are heterocycles which possess three nitrogen atoms in a five-membered ring. As ligands, 1,2,4-triazoles are extremely versatile and display the ability to act as monodentate, exobidentate $N(1), N(2)$ and exobidentate $N(2), N(4)$ when neutral or monodentate, exobidentate $N(1), N(2)$, exobidentate $N(1), N(4)$ and $N(1), N(2), N(4)$-tridentate when deprotonated. ${ }^{17}$

In pursuing our interest on chemical and biological aspects of palladium(II) complexes, ${ }^{14,18,19}$ we describe in this work the synthesis, spectroscopic characterization and thermal investigation of the two new 1,2,4-triazolylbridged polynuclear complexes $\left[\left\{\mathrm{PdCl}_{2}(\mu-\mathrm{Htrz})\right\}_{\mathrm{n}}\right]$ (1) and $\left[\left\{\mathrm{PdBr}_{2}(\mu \text {-Htrz })\right\}_{n}\right](2)$. We also investigated the immunomodulatory effects of the compounds 1,2,4-triazole (Htrz), 1, 2, and cisplatin by the release of $\mathrm{NO}$ and $\mathrm{H}_{2} \mathrm{O}_{2}$ in the culture supernatants of treated murine peritoneal cells.

\section{Experimental}

\section{Materials}

The materials employed in the syntheses were all commercially available and were used without purification. All solvents were dried and stored over molecular sieves prior to use. Cisplatin aqueous solution $\left(\mathrm{d}=1 \mathrm{~g} \mathrm{~mL}^{-1}, \mathrm{~F}\right.$. H. Faulding \& Co Limited - Australia) was generously supplied by Centro Oncológico da Região de Araraquara (C.O.R.A.).

\section{Synthesis of $\left[\mathrm{PdCl}_{2}\left(\mathrm{MeCN}_{2}\right]\right.$}

The precursor compound was prepared as described for $\left[\mathrm{PdCl}_{2}(\mathrm{PhCN})_{2}\right] \cdot{ }^{20} \mathrm{In}$ an erlenmeyer containing $40 \mathrm{~mL}$ of boiling acetonitrile under intense magnetic stirring, palladium(II) chloride $(2.00 \mathrm{~g} ; 11.3 \mathrm{mmol})$ was slowly added. The reaction mixture was stirred at $80^{\circ} \mathrm{C}$ for about $30 \mathrm{~min}$. The yellow suspension was filtered off and the obtained solid was washed with acetonitrile and dried under vacuum. Yield $75 \%$. Anal. Calcd. for $\mathrm{C}_{4} \mathrm{H}_{6} \mathrm{Cl}_{2} \mathrm{~N}_{2} \mathrm{Pd}$ (\%): C, 18.52; N, 10.80; H, 2.34. Found: C, 18.28; N, $10.40 ; \mathrm{H}, 2.49$.

Synthesis of $\left[\left\{\mathrm{PdCl}_{2}(\mu-\mathrm{Htrz})\right\}_{n}\right](\mathbf{1})$

Compound 1 was prepared by adding dropwise $\left[\mathrm{PdCl}_{2}(\mathrm{MeCN})_{2}\right](300 \mathrm{mg} ; 1.16 \mathrm{mmol})$ suspended in $15 \mathrm{~mL}$ 
of $\mathrm{H}_{2} \mathrm{O}$ to a solution of 1,2,4-triazole ( $88 \mathrm{mg} ; 1.27 \mathrm{mmol}$ ) in $2 \mathrm{~mL}$ of a mixture $\mathrm{H}_{2} \mathrm{O}: \mathrm{HCl} \mathrm{1:1.} \mathrm{After} \mathrm{stirring} \mathrm{for}$ $30 \mathrm{~min}$ at $50{ }^{\circ} \mathrm{C}$, the yellow suspension was filtered off and the obtained solid was washed with methanol and dried under vacuum. (Yield 45\%). $\mathrm{mp}>350{ }^{\circ} \mathrm{C}$. Anal. Calcd. for $\mathrm{C}_{2} \mathrm{H}_{3} \mathrm{Cl}_{2} \mathrm{~N}_{3} \mathrm{Pd}(\%)$ : C, 9.75; N, 17.05; H, 1.23. Found: C, 9.98; N, 17.36; H, 1.01. Selected IR frequencies $\left(v_{\max } / \mathrm{cm}^{-1}\right): 3171, v \mathrm{CH} ; 2991, \mathrm{vCH} ; 1535, v_{\text {ring }} ; 1418, \nu_{\text {ring }}$; $1317, \delta \mathrm{CH} ; 1080, \delta \mathrm{CH} ; 775, \gamma \mathrm{NH} ; 656, \gamma_{\text {ring }} ; 627, \gamma_{\text {ring }}$.

Synthesis of $\left[\left\{\mathrm{PdBr} r_{2}(\mu-H t r z)\right\}_{n}\right](2)$

Compound 2 was prepared by adding dropwise $\left[\mathrm{PdCl}_{2}(\mathrm{MeCN})_{2}\right]$ (300 mg; $1.16 \mathrm{mmol}$ ) suspended in $15 \mathrm{~mL}$ of $\mathrm{H}_{2} \mathrm{O}$ to a solution of 1,2,4-triazole ( $88 \mathrm{mg} ; 1.27 \mathrm{mmol}$ )

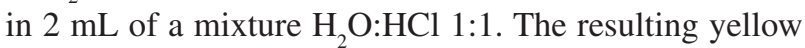
suspension became yellow-orange after addition of $\mathrm{KBr}$ (344 mg; $2.89 \mathrm{mmol}$ ) dissolved in $15 \mathrm{~mL}$ of $\mathrm{H}_{2} \mathrm{O}$. After stirring for $30 \mathrm{~min}$ at $50{ }^{\circ} \mathrm{C}$, the suspension was filtered off and the obtained solid was washed with methanol and dried under vacuum. (Yield 50\%). $\mathrm{mp}>350{ }^{\circ} \mathrm{C}$. Anal. Calcd. for $\mathrm{C}_{2} \mathrm{H}_{3} \mathrm{Br}_{2} \mathrm{~N}_{3} \mathrm{Pd}(\%)$ : C, 7.16; N, 12.53; H, 0.90 . Found: $\mathrm{C}, 6.89 ; \mathrm{N}, 12.36 ; \mathrm{H}, 1.12$. Selected IR frequencies $\left(v_{\max } / \mathrm{cm}^{-1}\right): 3169, \mathrm{vCH} ; 2991, \mathrm{vCH} ; 1533, v_{\text {ring }} ; 1417, v_{\text {ring }}$; $1317, \delta \mathrm{CH} ; 1082, \delta \mathrm{CH} ; 777, \gamma \mathrm{NH} ; 656, \gamma_{\text {ring }} ; 627, \gamma_{\text {ring }}$.

\section{Instrumental}

Elemental analyses of carbon, nitrogen and hydrogen were performed on a microanalyser Perkin-Elmer model 240 at Central Analítica - Instituto de Química USP-SP. Infrared spectra (IR) were recorded as $\mathrm{KBr}$ pellets on a Nicolet FTIR-Impact 400 spectrophotometer in the spectral range of $4000-400 \mathrm{~cm}^{-1}$. Diffuse reflectance spectra in UV-visible range were registered on a Cary 5000 spectrophotometer using $\mathrm{MgO}$ as reference. Thermal analyses (TG) were carried out using a Mettler Toledo TG-50, under flow of dry synthetic air $\left(100 \mathrm{~mL} \mathrm{~min}^{-1}\right)$, temperature up to $900^{\circ} \mathrm{C}$ and heating rate of $20^{\circ} \mathrm{C} \mathrm{min}^{-1}$, in $\alpha$-alumina sample holders. X-ray powder patterns of the residues were obtained with a Siemens D-5000 X-ray diffractometer using $\mathrm{CuK}_{\alpha}$ radiation $(\lambda=1.541 \AA)$ and setting of $40 \mathrm{kV}$ and $20 \mathrm{~mA}$. The peaks were identified using ICDD bases for $\mathrm{Pd}^{\circ}$ (ASTM 05-0681) and PdO (ASTM 06-0515). ${ }^{21}$

\section{Animals}

Female 6-8 weeks old BALB/c mice weighing 18 to $25 \mathrm{~g}$ were purchased from Universidade Estadual de Campinas (UNICAMP) central animal facilities CEMIB
(Centro Multidisciplinar para Investigação Biológica), SP, Brazil. They were maintained in polycarbonate boxes at $23 \pm 2{ }^{\circ} \mathrm{C}, 56 \pm 2 \%$ humidity, at $12 \mathrm{~h} \mathrm{light/dark} \mathrm{cycle,} \mathrm{kept}$ under specific-pathogen-free conditions (positive-pressure cabinet) and provided sterilized food and water ad libitum in accordance with the protocols of the Universidade Estadual Paulista (UNESP). All the experiments were carried out following the Federal Government legislation on animal care.

\section{Peritoneal macrophage}

Thioglycollate-elicited peritoneal exsudate cells (PEC) were harvested from female BALB/c mice using $5.0 \mathrm{~mL}$ of sterile PBS, $\mathrm{pH}$ 7.4. The cells were washed twice by centrifugation at $200 \mathrm{rpm}$ for $5 \mathrm{~min}$ at $4{ }^{\circ} \mathrm{C}$ and re-suspended in appropriate medium for each test.

\section{Cytotoxicity evaluation}

For the determination of the cytotoxic effect, the PEC were plated at a concentration of $5 \times 10^{6}$ per well in RPMI 1640 (Gibco), supplemented with $10 \%$ fetal bovine serum (FBS) (Cult-Lab), $100 \mathrm{U} \mathrm{mL}^{-1}$ of penicillin, $100 \mu \mathrm{g} \mathrm{mL}^{-1}$ of streptomycin, $2 \mathrm{mmol} \mathrm{L}^{-1}$ of L-glutamine, and $5 \times 10^{-2} \mathrm{~mol} \mathrm{~L}^{-1}$ of 2-mercaptoethanol (Sigma); this mixture was named complete RPMI-1640 (RPMI 1640-C). Then, samples of $100 \mu \mathrm{L}$ of peritoneal cells suspension $\left(5 \times 10^{6} \mathrm{cell} \mathrm{mL}^{-1}\right)$ in RMPI-1640-C medium were added to each well of a 96-well tissue culture plate with $100 \mu \mathrm{L}$ of different concentrations of samples: 1,2,4-triazole (Htrz), $\left[\left\{\mathrm{PdCl}_{2}(\mu-\mathrm{Htrz})\right\}_{\mathrm{n}}\right](\mathbf{1})$, $\left[\left\{\mathrm{PdBr}_{2}(\mu-\mathrm{Htrz})\right\}_{\mathrm{n}}\right](\mathbf{2})$, and cisplatin (standard drug) containing 0.1\% DMSO and RPMI 1640-C medium. Cells were incubated for $24 \mathrm{~h}$ at $37^{\circ} \mathrm{C}$ in a humidified atmosphere containing $7.5 \%$ of $\mathrm{CO}_{2}$. After incubation, the medium was poured off, and macrophages were incubated with $100 \mu \mathrm{L}$ of solution of 3-(4,5-dimethylthiazol-2-yl)-2,5-diphenyltetrazoliumbromide) (MTT) in each well. MTT assay was performed and the plates were incubated for $3 \mathrm{~h}$ at $37^{\circ} \mathrm{C}$ and $7.5 \% \mathrm{CO}_{2}$. The formazan formed was dissolved with $100 \mu \mathrm{L}$ of isopropyl alcohol and the optical density was measured using a microplate reader (Multiskan, Labsystem) equipped with a $540 \mathrm{~nm}$ filter and $620 \mathrm{~nm}$ reference filter. The optical density of dissolved formazan in the control (untreated cells) was taken as $100 \%$ of viability. ${ }^{22}$

\section{$\mathrm{H}_{2} \mathrm{O}_{2}$ measurement}

PEC at $2 \times 10^{6}$ cells $\mathrm{mL}^{-1}$ were suspended in a solution containing $140 \mu \mathrm{mol} \mathrm{L}{ }^{-1}$ of $\mathrm{NaCl}, 10 \mu \mathrm{mol} \mathrm{L}^{-1}$ of potassium phosphate buffer, $\mathrm{pH}$ 7.0, $5.5 \mu \mathrm{mol} \mathrm{L}^{-1}$ of 
dextrose, $0.56 \mu \mathrm{mol} \mathrm{L}^{-1}$ of phenol red, and $0.01 \mu \mathrm{g} \mathrm{mL} \mathrm{L}^{-1}$ of type II horseradish peroxidase (HRP). Next, $100 \mu \mathrm{L}$ of this suspension was added to each of the wells of a 96-well flat-bottom tissue culture plate and exposed to $\mathrm{IC}_{25}$ and $\mathrm{IC}_{50}$ concentrations of samples: 1,2,4-triazole (Htrz), $\left[\left\{\mathrm{PdCl}_{2}(\mu-\mathrm{Htrz})\right\}_{\mathrm{n}}\right](\mathbf{1}),\left[\left\{\mathrm{PdBr}_{2}(\mu-\mathrm{Htrz})\right\}_{\mathrm{n}}\right](\mathbf{2})$, and cisplatin (standard drug) containing 0.1\% DMSO $(50 \mu \mathrm{L})$ and phorbol myristate acetate (PMA) $0.2 \mu \mathrm{mol} \mathrm{L}^{-1}(50 \mu \mathrm{L})$. Cells incubated only with PMA were used as a positive control. The cells were incubated for $1 \mathrm{~h}$ at $37^{\circ} \mathrm{C}$ in a $7.5 \%$ $\mathrm{CO}_{2}$ atmosphere. The reaction was stopped with $50 \mu \mathrm{L}$ of $5 \mathrm{~mol} \mathrm{~L}^{-1}$ of $\mathrm{NaOH}$ and the samples were read at $620 \mathrm{~nm}$ with a Multiskan Ascent ELISA reader (Labsystems) against a blank containing phenol red solution and $5 \mathrm{~mol} \mathrm{~L}^{-1}$ of $\mathrm{NaOH}$. The results were expressed as nmol of $\mathrm{H}_{2} \mathrm{O}_{2} \mathrm{~mL}^{-1}$ cells, from a standard curve established in each test consisting of known molar concentrations of $\mathrm{H}_{2} \mathrm{O}_{2}$ in buffered phenol red. ${ }^{23,24}$

\section{NO measurements}

The nitric oxide (NO) production was determined by measuring nitrite $\left(\mathrm{NO}_{2}^{-}\right)$, a stable degradation product of nitric oxide by assaying culture supernatants. ${ }^{25}$ PEC at $5 \times 10^{6}$ cells $\mathrm{mL}^{-1}$ was incubated with $\mathrm{IC}_{25}$ and $\mathrm{IC}_{50}$ concentrations of the samples: 1,2,4-triazole (Htrz), $\left[\left\{\mathrm{PdCl}_{2}(\mu-\mathrm{Htrz})\right\}_{\mathrm{n}}\right](\mathbf{1}),\left[\left\{\mathrm{PdBr}_{2}(\mu-\mathrm{Htrz})\right\}_{\mathrm{n}}\right](\mathbf{2})$, and cisplatin (standard drug) containing $0.1 \%$ DMSO and RPMI 1640-C medium for $24 \mathrm{~h}$ at $37^{\circ} \mathrm{C}$ in a $7.5 \% \mathrm{CO}_{2}$ atmosphere. Cell-free supernatant $(50 \mu \mathrm{L})$ was mixed with $50 \mu \mathrm{L}$ of Griess reagent (sulfanilamide $0.1 \%$, phosphoric acid $3 \%$, naphthylethylenediamine $0.1 \%$ ) and incubated at room temperature for $10 \mathrm{~min}$. Cells incubated with lipopolysaccharide (LPS) $\left(1 \mathrm{mg} \mathrm{mL}^{-1}\right)$ were used as a positive control. After incubation, the absorbance was determined by using a microplate reader (Multiskan, Labsystem) equipped with a $540 \mathrm{~nm}$ filter. Nitrite concentration was determined using dilutions of sodium nitrite in culture medium as standards.

\section{Statistical analysis}

Results are representative of three independent experiments and they are presented as Means \pm Standard Deviation from quadruplicate observations. Data were analyzed statistically by the ANOVA by variance test and after by Tukey-Kramer post-test, using significance level $\mathrm{p}<0.05$, in the Graph Instat Pad ${ }^{\mathrm{TM}}$ software.

\section{Results and Discussion}

The precursor $\left[\mathrm{PdCl}_{2}(\mathrm{MeCN})_{2}\right]$ reacts with 1,2,4-triazole (Htrz) in water to afford $\left[\left\{\mathrm{PdCl}_{2}(\mu-\mathrm{Htrz})\right\}_{\mathrm{n}}\right](\mathbf{1})$. The $\left[\left\{\mathrm{PdBr}_{2}(\mu-\mathrm{Htrz})\right\}_{\mathrm{n}}\right](2)$ is readily synthesized by metathesis of the chloro groups in $\mathbf{1}$ with potassium bromide. A general scheme illustrating the strategy employed for the synthesis of the complexes $\mathbf{1}$ and $\mathbf{2}$ is illustrated in Scheme 1.

The coordination polymers $\mathbf{1}$ and $\mathbf{2}$ were obtained as air stable solids. The elemental analyses and thermogravimetric data, together with IR spectroscopy results, are consistent with the proposed formulae for the synthesized compounds. The polymeric nature of the obtained compounds was inferred by their low solubility, high thermal stability and amorphous nature as evidenced by powder $\mathrm{X}$-ray diffraction analysis (data not shown). Although 1,2,4-triazole is a simple molecule, very few X-ray structures of its derivatives were reported. Most probably this is caused by the fact that this ligand almost always produces intractable solids with transition metal salts, which is a typical characteristic of almost all linear coordination polymers. ${ }^{17,26-28}$

\section{Spectroscopic studies}

The IR spectrum of the free Htrz exhibits two bands attributed to the ring torsion mode $\left(\tau_{1}\right.$ and $\left.\tau_{2}\right)$ at 684 and $651 \mathrm{~cm}^{-1}$, respectively, since 1,2,4-triazole is found predominately, in the solid state, as the $1 H$-tautomer of $C_{s}$ symmetry. The coordination mode of $1 H-1,2,4$-triazole ligand can be inferred on basis of the number of ring torsion bands at $700-600 \mathrm{~cm}^{-1}$ range. ${ }^{29}$ Two ring torsion absorptions are expected when Htrz possesses $C_{s}$ local symmetry (monodentate and exobidentate $N(2), N(4)$ modes) resembling the IR spectrum of the solid free base. On the other hand, the exobidentate $N(1), N(2)$ and $N(1), N(2), N(4)$-tridentate coordination modes $\left(C_{2 v}\right)$ are characterized by the disappearance or decrease in intensity of the band associated with the first ring torsion vibration $\left(\tau_{1}\right)$. Therefore, the presence of the two bands at $656\left(\tau_{2}\right)$ and $629 \mathrm{~cm}^{-1}\left(\tau_{1}\right)$ for $\mathbf{1}$ and $\mathbf{2}$ strongly supports the local $C_{s}$ point group for $1 H$-1,2,4-triazole in these compounds.

There is an important IR spectral difference between monodentate and exobidentate $N(2), N(4)$ coordination mode of $1 H$-1,2,4-triazole. ${ }^{30}$ The first ring torsion absorption $\left(\tau_{1}\right)$ occurs at $c a .640 \mathrm{~cm}^{-1}$ for monodentate complexes, whereas for the bidentate mode such band always appears at lower wavenumbers. Thus, the $\tau_{1}$ bands at $629 \mathrm{~cm}^{-1}$ found in the IR

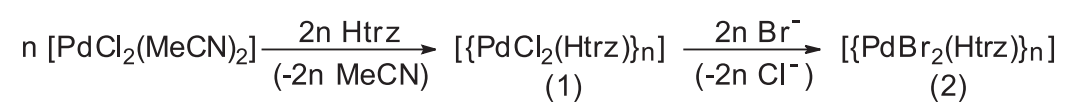


spectra of $\mathbf{1}$ and $\mathbf{2}$ (Figure 1) clearly indicate the $N(2), N(4)$ coordination mode of the 1H-1,2,4-triazole.

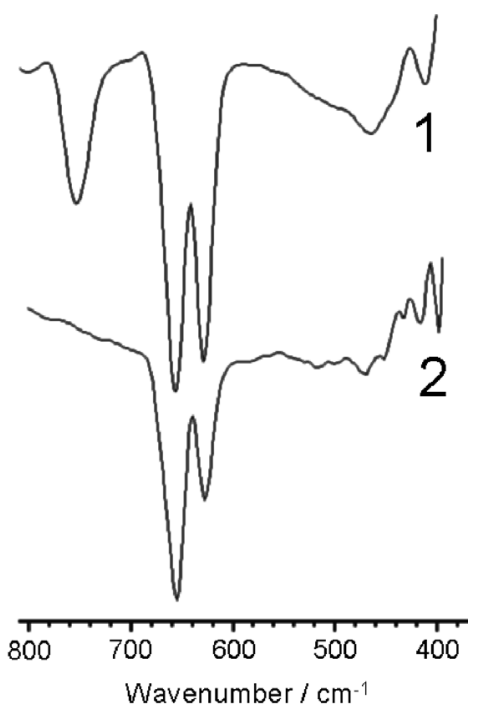

Figure 1. IR spectra of compounds $\mathbf{1}$ and 2.

In the diffuse reflectance electronic spectra of $\mathbf{1}$ and $\mathbf{2}$, the shift of the $\pi_{\mathrm{X}} \rightarrow d_{\mathrm{Pd}}(\mathrm{X}=\mathrm{Cl}, \mathrm{Br}$ ) LMCT (ligand-to-metal charge transfer) band from 258 (1) to $262 \mathrm{~nm}$ (2) is a strong evidence of the displacement of chloro by bromo ligands. Intense absorptions observed at $340-345 \mathrm{~nm}$ are attributed to MLCT (metal-to-ligand charge transfer) excitations of the type $d_{\mathrm{Pd}} \rightarrow \pi_{\mathrm{Htrz}}^{*}$. The $d-d$ absorptions were not observed and are probably obscured by the intense charge transfer bands. ${ }^{31}$

The analytical and spectroscopic data obtained for compounds $\mathbf{1}$ and $\mathbf{2}$ suggest that both exhibit 1D polymeric structures made by linear arrays of palladium(II). The coordination environment around palladium is expected to be square planar with the sites occupied by two halide groups $\left\{\mathrm{Cl}^{-}(\mathbf{1}), \mathrm{Br}(\mathbf{2})\right\}$, and two $\mathrm{N}$ atoms, one from each of the two $N(2), N(4)$-bridging Htrz ligands, in a trans configuration (Figure 2).

The assumption of the trans configuration of the products was based on the structure of the precursor. According to Belluco, complexes of the type cis- $\left[\mathrm{PdX}_{2}(\mathrm{RCN})_{2}\right]$ exhibit

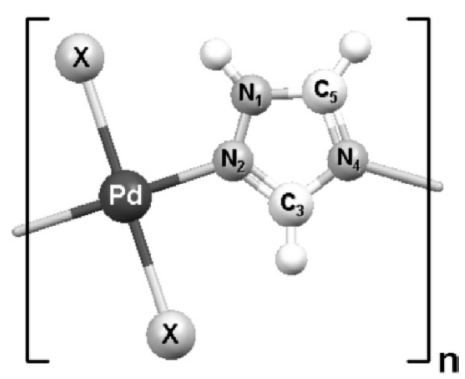

Figure 2. Proposed structure for complexes $\left[\left\{\mathrm{PdX}_{2}(\mathrm{Htrz})\right\}_{\mathrm{n}}\right]\{\mathrm{X}=$ $\mathrm{Cl}$ (1), $\mathrm{Br}(\mathbf{2})\}$. two IR strong bands in the $v_{\mathrm{CN}}$ region, whereas the trans analogues are characterized by only one $v_{\mathrm{CN}}$ band. ${ }^{32}$ Taking into account that the precursor used in our work just showed one intense $v_{\mathrm{CN}}$ band $\left(2330 \mathrm{~cm}^{-1}\right)$ in the IR spectrum, we infer the trans configuration for this compound. Such assumption is also in accordance with the literature. ${ }^{33,34}$

\section{Thermal analysis}

The TG curves for the compounds $\mathbf{1}$ and $\mathbf{2}$ are shown in Figure 3.

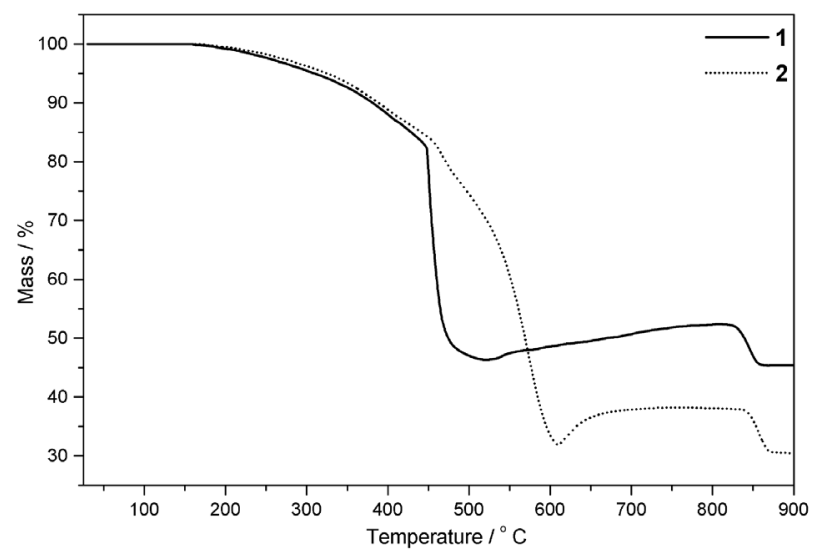

Figure 3. TG curves obtained for compounds $\mathbf{1}$ and $\mathbf{2}$.

The TG curves of these compounds showed a similar thermal degradation pattern in which the ligands are initially released in one or two stages, together with uptake of $\mathrm{O}_{2}$, leading to a mixture of $\mathrm{Pd}^{0}$ and $\mathrm{PdO}$. The slight mass increase up to $c a .800^{\circ} \mathrm{C}$ is ascribed to the oxidation of the remaining $\mathrm{Pd}^{0}$ to $\mathrm{PdO}$. Finally, the decomposition of $\mathrm{PdO}$ to $\mathrm{Pd}^{0}$ is completed at $c a .840{ }^{\circ} \mathrm{C}$. The final weight percent residues of 45.36 and $30.56 \%$ found for complexes $\mathbf{1}$ and 2, respectively, agree well with their respective calculated content of Pd $\{43.19 \%$ (1) and $31.74 \%$ (2) $\}$.

Cell viability of macrophages in the presence of the compounds Htrz, $\mathbf{1}$, and $\mathbf{2}$

Concentration-response cytotoxicity curves for $24 \mathrm{~h}$ exposure of macrophages to compounds Htrz, $\mathbf{1}$ and $\mathbf{2}$ were performed and the data were compared with the reference standard cisplatin (Table 1). The $\mathrm{IC}_{25}$ and $\mathrm{IC}_{50}$ results indicate that $\mathrm{Htrz}$ is significantly cytotoxic to macrophages. However, coordination of Htrz to palladium(II) in $\mathbf{1}$ dramatically reduces its cytotoxic activity. This fact can be associated to the modification of the electronic density around the Htrz molecule modifying the cellular targets of the new compound. It can be also observed from Table 1 
that the cytotoxicity was enhanced with the substitution of chloro (1) by bromo ligands (2), whose mechanism of interaction between the compounds and macrophages remains unknown. The reference standard cisplatin was found to be more cytotoxic than both palladium(II) compounds.

Effect of Htrz, 1, and 2 on $\mathrm{H}_{2} \mathrm{O}_{2}$ production by peritoneal macrophages

In order to determine the effect of $\mathrm{Htrz}, \mathbf{1}$, and $\mathbf{2}$ on $\mathrm{H}_{2} \mathrm{O}_{2}$ production by macrophages, these cells were treated with $\mathrm{IC}_{25}$ and $\mathrm{IC}_{50}$ concentrations of the tested compounds for $1 \mathrm{~h}$. The results depicted in Figure 4 summarize the release of $\mathrm{H}_{2} \mathrm{O}_{2}$ expressed as nmol $\mathrm{mL}^{-1}$ after $1 \mathrm{~h}$ of incubation with Htrz, 1, and 2.

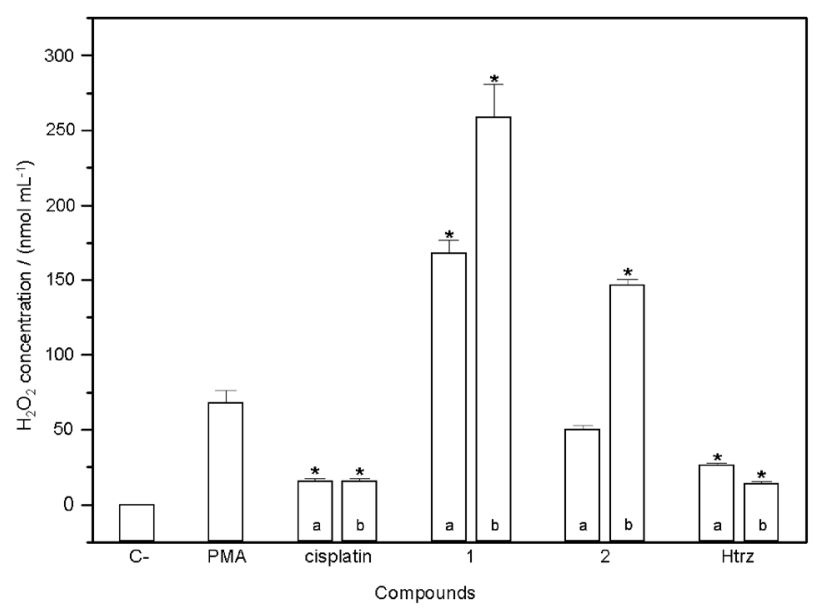

Figure 4. Effects of Htrz, 1, 2 and cisplatin at $\mathrm{IC}_{25}$ (a) and $\mathrm{IC}_{50}$ (b) concentrations on $\mathrm{H}_{2} \mathrm{O}_{2}$ production by mice peritoneal macrophages in vitro. Cells incubated with $0.2 \mu \mathrm{mol} \mathrm{L} \mathrm{L}^{-1}$ of PMA alone were used as a positive control. Each bar represents the mean \pm S.D. of four animals. Representative results of one experiment repeated four times are given. ${ }^{*} p<0.001$

Compounds 1 and 2 were able to stimulate $\mathrm{H}_{2} \mathrm{O}_{2}$ production by macrophages in a dose-dependent manner, releasing levels $c a$. 10-17 times higher than Htrz and cisplatin, at $\mathrm{IC}_{50}$ concentration. In addition, complexes $\mathbf{1}$ and 2 also induced the production of higher $\mathrm{H}_{2} \mathrm{O}_{2}$ levels when compared with the positive control PMA, a powerful immunostimulator.

Reactive oxygen species (ROS), including hydrogen peroxide, are strong oxidants which are toxic to cells and cause cellular and tissue damage at high concentrations. ${ }^{35}$ However, a sublethal concentration of hydrogen peroxide acts as potentially important signaling molecules in both intra and intercellular reactions in a number of different cell types. ${ }^{36}$ The high production of $\mathrm{H}_{2} \mathrm{O}_{2}$ by macrophages stimulated by $\mathbf{1}$ and $\mathbf{2}$ suggest that palladium(II) compounds would display a positive effect when used at lower concentrations than those tested in this work.

Measurement of $\mathrm{H}_{2} \mathrm{O}_{2}$ inhibition was also carried out in this study (data not shown). However, no inhibitory effect was detected for compounds $\mathbf{1}$ and $\mathbf{2}$ since they stimulated the production of high $\mathrm{H}_{2} \mathrm{O}_{2}$ levels by macrophages.

\section{Effect of Htrz, 1, and $\mathbf{2}$ on NO production by peritoneal macrophages}

The results illustrated in Figure 5 show the release of NO expressed as $\mu \mathrm{mol} \mathrm{mL} \mathrm{m}^{-1}$ of supernatant after $24 \mathrm{~h}$ of incubation with Htrz, 1, 2, and cisplatin.

When macrophages were treated with $\mathrm{IC}_{50}$ concentrations of $\mathbf{1}$ and $\mathbf{2}$ for $24 \mathrm{~h}$, the release of NO was reduced by about 3-4 times compared to that obtained at $\mathrm{IC}_{25}$. This significant reduction in NO production is related to the cytotoxic effects of the compounds in the experimental conditions used. Compounds $\mathbf{1}$ and $\mathbf{2}$ also stimulated the production of NO levels of $c a$. 3-4 times higher than Htrz and cisplatin, at $\mathrm{IC}_{25}$ concentration. Nevertheless, palladium(II) compounds induced the production of lower NO concentrations when compared with the positive control LPS. Lipopolysaccharide (LPS), one of the major constituents of the outer membrane of Gram-negative bacteria, is an important inflammatory mediator through innate host defense and well known for its high capacity to prime mouse macrophages to generate nitric oxide (NO) via $\mathrm{NF}-\kappa \mathrm{B} .{ }^{37,38}$ Stimulation of murine macrophages by

Table 1. Cytotoxicity of Htrz, 1, 2, and cisplatin in BALB/c peritoneal macrophages in vitro

\begin{tabular}{|c|c|c|c|c|}
\hline \multirow{2}{*}{ Compound } & \multicolumn{2}{|c|}{$\mathrm{IC}_{25}$} & \multicolumn{2}{|c|}{$\mathrm{IC}_{50}$} \\
\hline & $\mu \mathrm{mol} \mathrm{L}-1$ & $\operatorname{ng} \mu \mathrm{L}^{-1}$ & $\mu \mathrm{mol} \mathrm{L}{ }^{-1}$ & $\operatorname{ng} \mu \mathrm{L}^{-1}$ \\
\hline Htrz & $153.09 \pm 1.32$ & $10.6 \pm 0.09$ & $308.50 \pm 1.32$ & $21.3 \pm 0.09$ \\
\hline$\left[\left\{\mathrm{PdCl}_{2}(\mu-\mathrm{Htrz})\right\}_{\mathrm{n}}\right](\mathbf{1})$ & a & $449 \pm 13.7$ & a & $905 \pm 13.7$ \\
\hline$\left[\left\{\operatorname{PdBr}_{2}(\mu-\mathrm{Htrz})\right\}_{\mathrm{n}}\right](\mathbf{2})$ & a & $45.7 \pm 3.53$ & a & $416 \pm 3.53$ \\
\hline cisplatin & $18.88 \pm 2.14$ & $5.66 \pm 0.64$ & $62.88 \pm 2.14$ & $18.9 \pm 0.64$ \\
\hline
\end{tabular}

${ }^{a}$ not obtained since the molar weights of polymers $\mathbf{1}$ and $\mathbf{2}$ are unknown. 


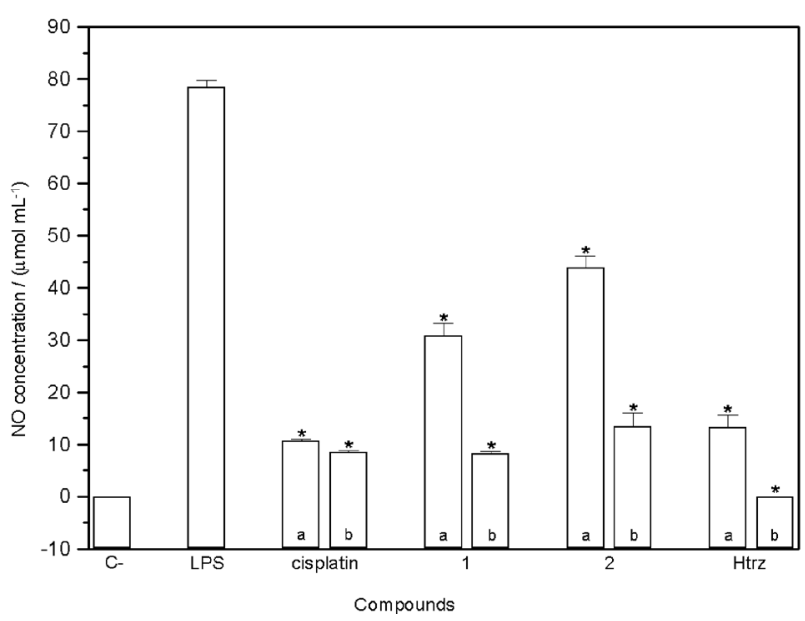

Figure 5. Effects of Htrz, 1, 2 and cisplatin at $\mathrm{IC}_{25}$ (a) and $\mathrm{IC}_{50}$ (b) concentrations on NO production by mice peritoneal macrophages in vitro. Cells incubated with $1 \mathrm{mg} \mathrm{mL}^{-1}$ of LPS alone were used as a positive control. Each bar represents the mean \pm S.D. of four animals. Representative results of one experiment repeated four times are given. $* p<0.001$

LPS results in the expression of an inducible NO synthase (iNOS), which catalyzes the synthesis of large amounts of NO from $L$-arginine and molecular oxygen. ${ }^{39}$

Since that the reduction of NO production is related to the cytotoxicity of the tested compounds, current assays using lower concentrations are underway in our laboratories.

\section{Conclusions}

The synthesis, characterization and immunological evaluation of two new triazolyl palladium(II) derivatives have been described in this work. The results of this study suggest that palladium(II) complexes display interesting immunomodulating activity on murine macrophages, despite the fact that the mechanisms of this action currently remain uncharacterized. It was evident that the substitution of chloro by bromo from the coordination sphere of the metal in the $\left[\left\{\operatorname{PdX}_{2}(\mu-\mathrm{Htrz})\right\}_{\mathrm{n}}\right]$ compounds results in the substantial increase of cytotoxicity towards macrophage cultures. Our preliminary in vitro findings also showed that macrophages respond to complexes $\mathbf{1}$ and $\mathbf{2}$ by enhancing $\mathrm{H}_{2} \mathrm{O}_{2}$ levels and releasing lower NO amounts than the positive control.

Further studies are in progress in our laboratories to elucidate the mechanism involved on the production of reactive toxic intermediates by palladium(II) compounds as well the cytokines production by the palladium(II) complex stimulated macrophages.

\section{Acknowledgments}

This work was sponsored by grants from FAPESP, CNPq and CAPES.

\section{References}

1. Schmidt, H. H. H. W.; Walter, U.; Cell 1994, 78, 919.

2. Moreira, R. R. D.; Carlos, I. Z.; Vilegas, W.; Biol. Pharm. Bull. 2001, 24, 201.

3. Nathan, C.; Cell 1995, 82, 873.

4. Nathan, C. F.; Hibbs, J. B. J.; Curr. Opin. Immunol. 1991, 3, 65.

5. Forman, H. J.; Torres, M.; Am. J. Respir. Crit. Care Med. 2002, $166, \mathrm{~S} 4$.

6. Guzik, T. J.; Korbut, R.; Adamek-Guzik, T.; J. Physiol. Pharmacol. 2003, 54, 469.

7. Ischiropoulos, H.; Nelson, J.; Duran, D.; Al-Medhdi, A.; Free Radical Biol. Med. 1996, 20, 373.

8. Linares, E.; Giorgio, S.; Mortara, R. A.; Santos, C. X. C.; Yamada, A. T.; Augusto, O.; Free Radical Biol. Med. 2001, 30, 1234.

9. Dusting, G. J.; MacDonald, P. S.; Ann. Med. 1995, 27, 395.

10. Achike, F. I.; Kwan, C. Y.; Clin. Exp. Pharmacol. Physiol. 2003, 30,605 .

11. Hobbs, A. J.; Higgs, A.; Moncada, S.; Annu. Rev. Pharmacol. Toxicol. 1999, 39, 191.

12. Bhimani, R. S.; Troll, W.; Grunberger, D.; Frenkel, K.; Cancer Res. 1993, 53, 4528.

13. Shishodia, S.; Sodhi, A.; Shrivastava, A; Int. J. Immunopharmac. 1997, 19, 683.

14. De Almeida, E. T.; Mauro, A. E.; Santana, A. M.; Netto, A. V. G.; Carlos, I. Z.; Quim. Nova 2005, 28, 405.

15. Nomiya, K.; Noguchi, R.; Ohasawa, K.; Tsuda, K.; Oda, M.; J. Inorg. Biochem. 2000, 78, 363 .

16. Reisner, E.; Arion, V. B.; Eichinger, A.; Kandler, N.; Giester, G.; Pombeiro, A. J. L.; Keppler, B. K.; Inorg. Chem. 2005, 44, 6704.

17. Haasnoot, J. G.; Coord. Chem. Rev. 2000, 200, 131.

18. Da Rocha, M. C.; Santana, A. M.; Ananias, S. R.; De Almeida, E. T.; Mauro, A. E.; Placeres, M. C. P.; Carlos, I. Z.; J. Braz. Chem. Soc. 2007, 18, 1473.

19. Caires, A. C. F.; De Almeida, E. T.; Mauro, A. E.; Hermely, J. P.; Valentini, S.; Quim. Nova 1999, 22, 329.

20. Heck, R. F.; Palladium Reagents in Organic Synthesis: Best Synthetic Methods, Academic Press: New York, 1985.

21. Powder Diffraction File of the Joint Committee on Power Diffraction Standards, published by the International Center of Diffraction Data, Swarthmore, PA, USA, 19081, 1982.

22. Mossman, T.; J. Immunol. Methods 1983, 65, 55.

23. Pick, E.; Keisari, Y.; J. Immunol. Methods 1980, 38, 161. 
24. Pick, E.; Mizel, D. J.; J. Immunol. Methods 1981, 46, 211.

25. Green, L. C. D.; Wagner, D. D. A.; Glogowski, J.; Skepper, P. L.; Wishnok, J. S.; Tannenbaum, S. R.; Ann. Biochem. 1982, 126, 131.

26. Janiak, C.; J. Chem. Soc., Dalton Trans. 2003, 2781.

27. Archer, R. D.; Coord. Chem. Rev. 1993, 128, 49.

28. Bailar Jr., J. C.; In Preparative Inorganic Reactions, Jolley, W. L., ed., Interscience: New York, 1964.

29. Haasnoot, J. G.; Vos, G.; Groeneveld, W. L.; Z. Naturforsch, B: Chem. Sci. 1977, 32, 533.

30. Haasnoot, J. G.; Vos, G.; Groeneveld, W. L.; Z. Naturforsch, B: Chem. Sci. 1977, 32, 1421.

31. Lever, A. B. P.; Inorganic Electronic Spectroscopy, Elsevier: Amsterdam, 1968.

32. Belluco, U.; Crociani, B.; Boschi, T.; Inorg. Chem. 1970, 9 , 2021.
33. Storhoff, B. N.; Lewis Jr., H. C.; Coord. Chem. Rev. 1977, $23,1$.

34. Walton, R. A.; Can. J. Chem. 1968, 46, 2347.

35. Schraufstatter, I. U.; Hyslop, P. A.; Hinshaw, D. B.; Spragg, R. G.; Sklar, L. A.; Cochrane, C. G.; Proc. Natl. Acad. Sci. U. S. A. 1986, 83, 4908.

36. Chua, C. C.; Hamdy, R. C.; Chua, B. H.; Free Radical Biol. Med. 1998, 25, 891.

37. Barratt, G. M.; Raddassi, K.; Petitm, J. F.; Tenu, J. P.; Int. J. Immunopharmacol. 1991, 13, 159.

38. Forstermann, U.; Gath, I.; Schwarz, P.; Closs, E. I.; Kleinert, H.; Biochem. Pharmacol. 1995, 50, 1321.

39. Palmer, R. M.; Ashton, D. S.; Moncada, S.; Nature 1988, 333, 664.

Received: February 21, 2008 Web Release Date: February 6, 2009

FAPESP helped in meeting the publication costs of this article. 